\title{
Convergence and Potential Economic Development in the Special Region of Yogyakarta
}

\author{
By: \\ Yustirania Septiani \\ Faculty of Economics, Tidar University \\ Email: yustirania.septiani@gmail.com
}

\begin{abstract}
This study aims to determine whether there is a lag between a region with another, to determine whether the regions with low income will be able to catch up with regions with higher income. The objectives of this study are to analyze the convergence that might occur in Yogyakarta and analyze the potential economic sectors in economic development in Yogyakarta. This study used panel secondary data, the data were obtained from 5 regions in Yogyakarta from 2010-2015. The methods were panel data regression, location quotient, dynamic location quotient, and shift share. The result showed that there was no convergence, but there was divergence, and competitive and specialized sectors in regencies / cities in Yogyakarta were agricultural, forestry, and fishing sector, mining and excavation sector, processing industry sector, procurement of electricity and gas sector, water supply, waste management and recycling sector, construction sector, and transportation and trade sector.
\end{abstract}

Keywords: Convergence, Potential Sector, Economic Development.

\begin{abstract}
ABSTRAK
Penelitian ini bertujuan untuk mengetahui apakah ada perbedaan antara suatu daerah dengan daerah lain, untuk menentukan apakah daerah dengan pendapatan rendah akan dapat mengejar ketinggalan dengan daerah dengan pendapatan lebih tinggi. Tujuan dari penelitian ini adalah untuk menganalisis konvergensi yang mungkin terjadi di Yogyakarta dan menganalisis sektor ekonomi potensial dalam pembangunan ekonomi di Yogyakarta. Penelitian ini menggunakan data sekunder panel, data diperoleh dari 5 daerah di Yogyakarta dari 2010-2015. Metode yang digunakan adalah regresi data panel, location quotient, dynamic location quotient, dan shift share. Hasil penelitian menunjukkan bahwa tidak ada konvergensi, tetapi ada divergensi, dan sektor kompetitif dan khusus di kabupaten / kota di Yogyakarta adalah sektor pertanian, kehutanan, dan perikanan, sektor pertambangan dan penggalian, sektor industri pengolahan, pengadaan sektor listrik dan gas, pasokan air, pengelolaan limbah dan sektor daur ulang, sektor konstruksi, dan sektor transportasi dan perdagangan.
\end{abstract}

Kata kunci: Konvergensi, Sektor Potensial, Pembangunan Ekonomi.

\section{INTRODUCTION}

Growth and equity are two poles of development strategies that are often trade off. This means that the development focusing on aspect of economic growth is likely to "sacrifice" the aspect of equity, and vice versa. Unfortunately, the policy choice generally falls on the policy of triggering high economic growth in the hope that equitable distribution of development outcomes will eventually be achieved through a trickle down effect. This means that the process of equalizing income will automatically occur after high economic growth occurs. 
However, the success of development in terms of this classical economic benchmark does not seem to be fully able to reflect the real reality of life in society. The figures shown by gross national product (GNP) or gross domestic product (GDP) are not sensitive to reveal the state of mind of the community. Moreover, there is a widening gap between the rich and the poor along with the rapid economic growth (Lincolin, 2010).

Based on the study conducted by Malik (2014), the speed of absolute convergence is faster than the speed of conditional convergence. Absolute convergence explains how the economy of a poor region has a tendency to grow faster than a rich region by looking at the real per capita GRDP growth (Kuncoro, 2013). This is based on the determinants of economic growth, such as foreign investment, different government spendings for each region, different level of human development index in each province in Indonesia. Prishardoyo (2008) stated that the greater the contribution given by each economic sector to the GRDP of a region, the better the economic growth. Economic growth seen from GRDP is one indicator to determine the success of development.

Daryanto (2004) emphasizes development as a consequence of the strong centralistic nature of development planning and implementation which causes inequality. The inequality between urban areas and rural areas is caused by differences in the speed of growth. Development disparities between regions can also be seen from inequality in a) per capita income, b) quality of human resources, c) availability of facilities and infrastructure such as transportation, energy and telecommunication, d) social services such as health, education, etc., and e) access to banking.

Williamson (1965) (in Kuncoro, 2004) examining the relationship between regional disparities and level of economic development using developed economy and developing economy data found that during the early stages of development, regional disparities were greater and development was concentrated in certain area. At a more mature stage of economic growth, there appeared to be a balance between regions and disparities that were significantly reduced. Development disparities between region and central region, and between one region and another are common, due to differences in resources and the initial implementation of inter-regional development. It can be said that one way to reduce development disparities regionally can be seen through specific local aspect. Specific local aspect refers to inward looking. The selection of priorities in the development goals to be taken refers to the needs of the community where in essence, the community welfare shall be prioritized.

BKKBN (Endrayani, 2016) states that the most important goal of development is poverty reduction, which can be achieved through high economic growth or with equitable income distribution. Thus, there is a triangular relationship between economic growth, income inequality and poverty. The relationship between economic growth and income inequality is a two-way relationship.

Based on data from the Central Statistics Agency, GRDP at Constant 2010 Price has increased from year to year according to the Business Field of Yogyakarta Province. This means that the economy in the Province of Yogyakarta runs well seeing from the prosperity of the community. The more prosperous of the population in an area, the higher its GRDP.

However based on the data, the level of income inequality in the province of Yogyakarta is higher. Even the income inequality in the Special Region of Yogyakarta is above the figure of national income inequality. According to the data released by the Central Statistics Agency (BPS), the value of gini ratio of the Province of Yogyakarta reached 0.440 , while the national figure was 0.391 . The value of gini ratio in Yogyakarta increased from 0.432 in March, 2017 to 0.440 in September, 2017.

This study has two objectives, namely to determine the convergence condition between regency/city areas in Yogyakarta, so that it can be determined the success of development in Yogyakarta, and to determine the potential economic sectors or leading sectors that can be developed as a development potentials.

By determining the convergence condition, it can be seen whether the poor regions with low income will grow faster than the rich regions with high income, so that it can be predicted that in the long term the regions will experience the same convergence. Then, by determining the potential sectors for development or basis sector, it can be used as a reference for the concentration of the driving sector that can increase regional income. 


\section{ANALYTICAL METHOD}

\section{Source and Data Collection Technique}

This study used panel secondary data. The data were obtained from 5 regencies / cities in Yogyakarta from 2010-2015. Data were obtained from various related agencies such as BPS, BAPPEDA, Capital Investment Coordinating Body and Regional Promotion. Data to determine convergence conditions include per capita GRDP, Human Development Index, Labor Force Participation Rate. While the data used in relation to regional potential was GRDP according to business field on the basis of constant 2010 prices.

\section{Data Analysis Method}

To answer the first research question, sigma convergence can be measured by calculating the dispersion of per capita income of a country or region. Dispersion calculation is based on the results of the standard deviation of the logarithm of per capita income (GRDP) between regions in Yogyakarta every year. If the standard deviation value decreases at any time, it indicates the occurrence of sigma convergence.

On the contrary, if the value of per capita GRDP logarithms does not decrease at any time, then it does not indicate the occurrence of sigma convergence. Due to the absence of sigma convergence, it can be concluded that there is no indication of a convergence or divergence. Then, the calculation of absolute convergence is based on the equation model developed by Barro and Sala-I-Martin, (Kuncoro, 2013) as follows:

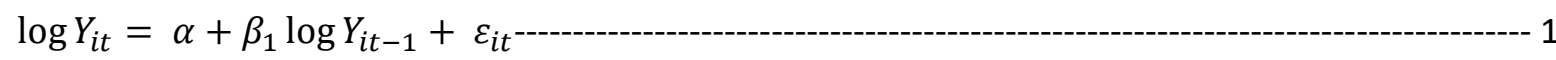

\section{Description:}

$Y_{i t}=$ per capita GRDP per province,

$Y_{i t}=$ per capita GRDP per initial province,

$\beta_{1}=$ a regression coefficient to calculate the convergence speed; and

$\varepsilon_{i t}=$ error term.

After the implementation of regional autonomy, the traditional convergence model uses equation (16) plus the independent varibles in this study: human index development (HDI) and labor force participation rate (LFPR) into the following equation (2):

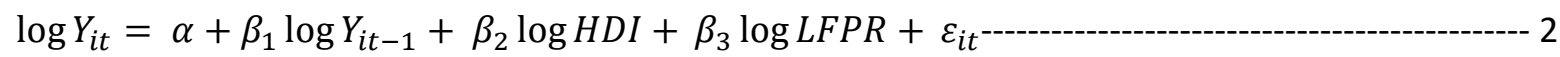

\section{Description:}

$Y_{i t} \quad=$ Provincial per capita GRDP

$Y_{i t-1}=$ Per capita GRDP in previous year

$H D I=$ Human development index

$L F P R \quad=$ Labor force participation rate

$i \quad=$ Region

$t \quad=$ Year

To answer the second research question, it is used Location Quotient (LQ) as follows (Arsyad, 2010):

$L Q=\frac{E i j / E j}{E i n / E n}$ 3

Description:

LQ : Location Quotient

Eij : Amount of GRDP of sector i of Regency/City in Yogyakarta 
Ej : Amount of total GRDP of Regency/City in Yogyakarta

Ein ; Amount of GRDP of sector i of Regency/City in Yogyakarta

En : Amount of total GRDP of Province of Yogyakarta.

As an alternative to complement the weaknesses of $L Q$ analysis, it is used Dynamic Location Quotient (DLQ). This method is used to determine the the role of priority sector. Thus, it can provide accurate outcome by referring to the growth rate of economic sector. The formulation of DLQ analysis is as follows (Yuwono, 2001):

$D L Q=\frac{S L Q t-S L Q t_{-} 1}{S L Q t-1}$ 4

Description:

SLQt : static location quotient in the current year

SLQt-1 : static location quotient in the previous year

Shift Share analysis is used to determine a shift in the structure of economic sector or sub-sector. Data used in shift share analysis is Regency/City GRDP in Yogyakarta according to the field of business on the basis of constant 2010 prices. The use of constant price data with the same base year, so that the quality (the real value) can be the same and the comparison is valid (Tarigan, 2005). Then, it is conducted an analysis on deviation as a comparison. If the deviation is positive, then it can be said that a sector in GRDP has a competitive advantage or vice versa.

\section{RESULT AND DISCUSSION}

Based on the result of data processing using linear regression method, it can be obtained the following result:

Table 1. Analysis Result of Absolute Convergence

Dependent Variable : LNPDRBPK

Method: Panel Least Squares

\begin{tabular}{lcccc}
\hline Variable & Coefficient & Error & t-Statistic & Prob. \\
\hline C & 2.536080 & 0.721942 & 3.512857 & 0.0018 \\
LNPDRBKT & 0.655032 & 0.099815 & 6.562441 & 0.0000 \\
R-squared & 0.954358 & & & \\
Adjusted R-Squared & 0.944849 & & \\
F-statistic & 100.3654 & Durbin-Watson Stat & 3.062281 \\
Prob (F-Statistic) & 0.0000 & & & \\
\hline
\end{tabular}

Source: Processed Data

Table 2. Analysis Result of Conditional Convergence

Dependent Variable: LNPDRBPK

\begin{tabular}{lcccc}
\hline Variable & Coefficient & Std.Error & t-Statistic & Prob \\
\hline C & 2.016508 & 2.009173 & 1.003651 & 0.3265 \\
LNPDRBKT & 0.460897 & 0.373043 & 1.235506 & 0.2297 \\
HDI & 0.026552 & 0.016144 & 1.644713 & 0.1142 \\
LFPR & $-1.07 \mathrm{E}-05$ & $1.05 \mathrm{E}-05$ & -1.020544 & 0.3186 \\
R-squared & 0.958292 & & & \\
Adjusted R-squared & 0.945021 & Durbin-Watson stat & 2.676328 \\
F-statistic & 72.21068 & & & \\
Prob(F-statistic) & 0.000000 & & \\
\hline \multicolumn{4}{c}{ Source: Processed Data }
\end{tabular}


Table 3. Result of Potential Economic Sector of Regency/City in Yogyakarta

\begin{tabular}{|c|c|c|c|c|c|c|}
\hline Category & Business Field & Kulonprogo & Bantul & $\begin{array}{l}\text { Gunung } \\
\text { Kidul }\end{array}$ & Yogyakarta & Sleman \\
\hline A & $\begin{array}{l}\text { Agriculture, forestry, } \\
\text { fishing sector }\end{array}$ & basis / + & $\begin{array}{l}\text { basis } \\
/+\end{array}$ & basis/+ & non basis/- & $\begin{array}{c}\text { non } \\
\text { basis/- }\end{array}$ \\
\hline B & $\begin{array}{l}\text { Mining and excavation } \\
\text { sector }\end{array}$ & basis /+ & basis /- & basis /+ & non basis/- & $\begin{array}{c}\text { non } \\
\text { basis/- }\end{array}$ \\
\hline C & Processing industry sector & non basis/- & $\begin{array}{l}\text { basis } \\
/+\end{array}$ & $\begin{array}{c}\text { non } \\
\text { basis/- }\end{array}$ & basis /+ & basis /- \\
\hline D & $\begin{array}{l}\text { Procurement of electricity } \\
\text { and gas sector }\end{array}$ & non basis/- & $\begin{array}{l}\text { basis } \\
\text { /+ }\end{array}$ & $\begin{array}{c}\text { non } \\
\text { basis/- }\end{array}$ & basis /- & $\begin{array}{c}\text { non } \\
\text { basis/- }\end{array}$ \\
\hline$E$ & $\begin{array}{l}\text { Water supply, waste } \\
\text { management and } \\
\text { recycling sector }\end{array}$ & basis /+ & $\begin{array}{c}\text { non } \\
\text { basis/- }\end{array}$ & basis/+ & basis /- & $\begin{array}{l}\text { non } \\
\text { basis/- }\end{array}$ \\
\hline $\mathrm{F}$ & Construction sector & non basis/- & $\begin{array}{l}\text { basis } \\
/+\end{array}$ & $\begin{array}{c}\text { non } \\
\text { basis/- }\end{array}$ & non basis/- & basis/+ \\
\hline G & $\begin{array}{l}\text { Wholesale and retail: car } \\
\text { and motorcycle repair } \\
\text { sector }\end{array}$ & basis /- & $\begin{array}{l}\text { non } \\
\text { basis/- }\end{array}$ & basis /- & non basis/- & $\begin{array}{c}\text { non } \\
\text { basis/- }\end{array}$ \\
\hline $\mathrm{H}$ & $\begin{array}{l}\text { Transportation and trade } \\
\text { sector }\end{array}$ & non basis/- & $\begin{array}{l}\text { non } \\
\text { basis/- }\end{array}$ & $\begin{array}{l}\text { non } \\
\text { basis }\end{array}$ & non basis & basis /+ \\
\hline । & $\begin{array}{l}\text { Provision of } \\
\text { accomodation, food and } \\
\text { beverage sector }\end{array}$ & non basis/- & basis /- & $\begin{array}{c}\text { non } \\
\text { basis/- }\end{array}$ & basis /- & basis /- \\
\hline J & $\begin{array}{l}\text { Information and } \\
\text { communication sector }\end{array}$ & non basis/- & $\begin{array}{l}\text { non } \\
\text { basis/- }\end{array}$ & $\begin{array}{c}\text { non } \\
\text { basis/- }\end{array}$ & basis /- & $\begin{array}{c}\text { non } \\
\text { basis/- }\end{array}$ \\
\hline K & $\begin{array}{l}\text { Financial and insurance } \\
\text { services sector }\end{array}$ & non basis/- & $\begin{array}{c}\text { non } \\
\text { basis/- }\end{array}$ & $\begin{array}{c}\text { non } \\
\text { basis/- }\end{array}$ & basis /- & $\begin{array}{c}\text { non } \\
\text { basis/- }\end{array}$ \\
\hline $\mathrm{L}$ & real estate sector & non basis/- & $\begin{array}{c}\text { non } \\
\text { basis/- }\end{array}$ & $\begin{array}{c}\text { non } \\
\text { basis/- }\end{array}$ & basis /- & basis /- \\
\hline $\mathrm{Mn}$ & Company services sector & non basis/- & $\begin{array}{l}\text { non } \\
\text { basis/- }\end{array}$ & $\begin{array}{c}\text { non } \\
\text { basis/- }\end{array}$ & basis /- & basis /- \\
\hline $\mathrm{O}$ & $\begin{array}{l}\text { Government } \\
\text { administration, defense } \\
\text { and mandatory social } \\
\text { security sector }\end{array}$ & basis /- & $\begin{array}{c}\text { non } \\
\text { basis/- }\end{array}$ & basis/- & basis /- & $\begin{array}{c}\text { non } \\
\text { basis/- }\end{array}$ \\
\hline$P$ & Education service sector & non basis/- & $\begin{array}{l}\text { non } \\
\text { basis/- }\end{array}$ & $\begin{array}{c}\text { non } \\
\text { basis/- }\end{array}$ & basis /- & basis /- \\
\hline Q & $\begin{array}{l}\text { Health service and social } \\
\text { activities sector }\end{array}$ & non basis/- & $\begin{array}{l}\text { non } \\
\text { basis/- }\end{array}$ & $\begin{array}{c}\text { non } \\
\text { basis/- }\end{array}$ & basis /- & $\begin{array}{c}\text { non } \\
\text { basis/- }\end{array}$ \\
\hline Rstu & Other services & basis /- & $\begin{array}{c}\text { non } \\
\text { basis/- }\end{array}$ & basis /- & basis /- & $\begin{array}{c}\text { non } \\
\text { basis/- }\end{array}$ \\
\hline
\end{tabular}

After conducting classical assumption test, it can be determined that there is no deviation. Thus, the equation of estimation result is analyzed using statistical tests, including $F$ test, $t$ test, and coefficient of determination $\left(R^{2}\right)$. Based on the result of absolute convergence analysis 1 , it is obtained the probability value of F-test of 0.000000 smaller than the significance level $\alpha(0.05)$. This indicates that per capita GRDP variable has an effect on the average economic growth in 2010- 2015.

The estimation result of conditional convergence in Table 5.1 shows the probability value of Ftest of 0.000000 smaller than $\alpha(0.05)$. This indicates that the independent variables (per capita GRDP at constant 2010 prices, Human Development Index, Labor Force Participation Rate) simultaneously have an effect on the average economic growth in 2010-2015. Based on the result in Table 1, it is 
obtained t-count value for per capita GRDP variable of 6.57 greater than t-table value. This indicates that per capita GRDP variable partially has a positive effect on the average economic growth in 20102015. From the estimation result of absolute convergence by looking at the positive regression coefficient, it can be concluded that there is no convergence, but there is a divergence in the regency/city, meaning that there is lagging and inequality.

Based on table 5.3, it can be explained that each Regency/City has a comparative advantage which can be used as an initial sign that the commodity has a prospect of having a competitive advantage and specialization.

Kulonprogo Regency has a competitive advantage and is specialized in three sectors, namely agriculture, forestry and fishing sector, mining and excavation sector, and water supply, waste management and recycling sector. Bantul Regency has a competitive and is specialized in four sectors, namely agriculture, forestry and fishing sector, processing industry sector, procurement of electricity and gas sector, and construction sector. Gunung Kidul Regency has a competitive advantage and is specialized in three sectors, namely agriculture, forestry and fishing sector, mining and excavation sector, and water supply, waste management and recycling sector. Yogyakarta City has a competitive advantage and is specialized in a sector, namely processing industry sector. Sleman Regency has a competitive advantage and is specialized in two sectors, namely construction sector and transportation and trade sector.

\section{CONCLUSION}

The conclusions of this study are that based on the estimation result of absolute convergence, it can be seen that there was no convergence, but there was a divergence in regencies/cities in Yogyakarta, meaning that there was lagging and inequality. Based on the result of conditional convergence analysis, it showed that convergence did not occur in Indonesia in 2010-2015. Therefore, it can be concluded that divergence occurred. Based on the analysis of potential, it can be determined sectors with competitive advantages and specialization that should get special attention from the government of Yogyakarta, the sectors were agriculture, forestry and fishing sector, mining and excavation sector, processing industry sector, procurement of electricity and gas sector, water supply, waste management and recycling sector, construction sector, and transportation and trade sector.

The suggestions of this study are that local government, both regency and city in Yogyakarta should work together to improve both potential and non-potential sectors in order to equalize the development between one region and another. For further studies, the author should add the time span of research data of before regional autonomy and after regional autonomy as a comparison, so that the results will be more accurate.

\section{REFFERENCES}

Arsyad, L. (2010). Economic development (fifth edition). Yogyakarta: STIM YKPN.

Central Bureau of Statistics. Gini Ratio of regencies / cities in Special Region of Yogyakarta in 20092015. Yogyakarta: Central Bureau of Statistics of Yogyakarta Province.

Regencies / cities human development index in Special Region of Yogyakarta in 2009-2015. Yogyakarta: Central Bureau of Statistics of Yogyakarta Province.

GRDP on prices applicable to regencies / cities in Special Region of Yogyakarta in 2009-2015. Yogyakarta: Central Bureau of Statistics of Yogyakarta Province.

Regencies / cities regional revenue in Special Region of Yogyakarta in 2009-2015. Central Yogyakarta: Central Bureau of Statistics of Yogyakarta Province.

Daryanto, A. (2004). Advantages of competitiveness and the technique of identifying superior commodities in developing regional economics. AGRIMEDIA, 9(2), 51-62.

Development Analysis Series of Special Region of Yogyakarta Province in 2015. Retrieved from simreg.bappenas.go.id/view/publikasi. Accessed on December $28^{\text {th }}, 2017$. 
Endrayani, N. K. E. \& Dewi, M. H. U. (2016). Analysis of factors affecting poverty levels in districts / cities in Bali Province. E-Journal of Economics and Business, 5(1), 63-88.

Kuncoro, M. (2013). Easy to understand and analyze economic indicators (first edition). Yogyakarta: UPP STIM YKPN. . (2003). Research methods for business and economics. Jakarta: Erlangga.

Malik, A. S. (2014). Analysis of convergence between provinces in indonesia after implementation of regional autonomy in 2001-2012. Journal of Economics and Policy, 7(1), 92-101.

Prishardoyo, B. (2008). Analysis of economic growth rate and economic potential of Pati Regency's gross regional domestic product (GRDP) in 2000-2005. Journal of Economics and Policy, 1(1), 19.

Tarigan, R. (2005). Regional economic: theory and applications (revised edition). Jakarta: Bumi Askara.

Yuwono, P. (2001). Determination of regional superior sectors facing the implementation of law 22/1999 and law no. 25/1999. Critical, 12(2), 16-32. 